\title{
Purification and some properties of the D-lactate-2-sulphatase of Pseudomonas syringae GG
}

\author{
Allan M. V. CRESCENZI, Kenneth S. DODGSON and Graham F. WHITE \\ Department of Biochemistry, University College Cardiff, Cardiff CF1 IXL, U.K.
}

(Received 14 May 1984/Accepted 12 July 1984)

\begin{abstract}
A soil bacterium grown on propan-2-yl sulphate as sole source of carbon and sulphur yielded extracts containing an enzyme capable of liberating sulphate from racemic lactate-2-sulphate. The enzyme was purified to homogeneity by a combination of streptomycin sulphate precipitation of nucleic acids, batch treatment with DEAEcellulose, and chromatography on columns of DEAE-cellulose, Sephacryl S-300 and butyl-agarose. The protein was monomeric with an $M_{\mathrm{r}}$ of 55000-60000. The enzyme activity was specific for D-lactate-2-sulphate $\left(K_{\mathrm{m}} 6.6 \mathrm{nM}\right.$; maximal specific activity $14.3 \mu \mathrm{mol} / \mathrm{min}$ per $\mathrm{mg}$ of protein) and showed no activity towards the L-isomer. The products of the enzyme's action were inorganic sulphate and D-lactate which were released in equimolar amounts and stoicheiometrically with the amount of ester hydrolysed. No L-lactate was formed. Retention of configuration implied cleavage of the $\mathrm{O}-\mathrm{S}$ bond of the $\mathrm{C}-\mathrm{O}-\mathrm{S}$ ester link and this was confirmed by ${ }^{18} \mathrm{O}$-incorporation experiments in which ${ }^{18} \mathrm{O}$ from ${ }^{18} \mathrm{O}$-enriched water in the incubation medium was incorporated exclusively and quantitatively into inorganic sulphate. Only two other esters (serine- $O$-sulphate and $p$-nitrophenyl sulphate) of a total of 29 compounds tested were substrates for the enzyme. D-Lactate, L-lactate-2-sulphate and the substrate analogues glycollate-2-sulphate and butyrate-2-sulphate were significantly inhibitory.
\end{abstract}

Studies in these laboratories (see Dodgson et al., 1982; Dodgson \& White, 1983, for summaries) have established that the biodegradation of primary and secondary alkyl sulphate surfactants is initiated by primary and secondary alkylsulphatase enzymes, some of the latter being stereospecific. However, these enzymes are apparently unable to deal with alkyl sulphates with alkyl chains containing fewer than five carbon atoms. It is known that short-chain alkyl sulphates do exist in nature. For example, a number of these esters are present in the allantois of the developing chick egg, the major component being propan-2-yl sulphate (Yagi, 1964, 1966). Furthermore, the endproducts of the metabolism of alkyl sulphate surfactants in mammals and fish are short-chain sulphated compounds, e.g. butyric acid-4-sulphate is the major excretory product formed from the metabolism of sodium dodecyl sulphate in the rat (Denner et al., 1969). Industry also makes its contribution to short-chain alkyl sulphates in the environment, and methyl sulphate has been identified as a significant component of the air-borne particulate matter emitted from coal-burning power stations (Lee et al., 1980).

As part of a programme to investigate the ways in which these short-chain alkyl sulphates undergo biodegradation, a soil bacterium has been isolated which can grow on potassium propan-2-yl sulphate as the sole source of carbon, energy and sulphur. No sulphatase enzyme capable of using propan-2yl sulphate as substrate can be detected. However, a stereospecific enzyme that is able to remove the ester sulphate group from D-lactate-2-sulphate is produced by the bacterium. The present paper describes the purification and some properties of this new type of sulphatase.

\section{Materials and methods}

Unless stated otherwise, all chemicals were the purest available from Sigma or BDH. 2-Monochloropropionic acid, a gift from Professor $\mathbf{H}$. Slater, University of Wales Institute of Science and Technology, Cardiff, U.K., was converted to the potassium salt by neutralization with $\mathrm{KOH}$. 


\section{Chemical analysis}

Potassium contents of potassium alkyl sulphate esters were measured by flame photometry in an EEL flame photometer (Evans Electroselenium, Halstead, Essex, U.K.) with $\mathrm{KCl}$ as standard. Ester sulphate contents were measured gravimetrically by conversion to $\mathrm{BaSO}_{4}$, as described previously (White et al., 1980). Elemental analyses for $\mathrm{C}$ and $\mathrm{H}$ contents were performed using a Technicon CHN Autoanalyser standardized with acetanilide.

\section{Spectroscopic analysis}

I.r. spectra of samples incorporated either in Nujol mulls between $\mathrm{NaCl}$ plates, or in $\mathrm{KBr}$ disks, were obtained by using a Perkin-Elmer Infracord 137 Spectrometer. For n.m.r. spectroscopy, samples $(15-25 \mathrm{mg})$ were dissolved in ${ }^{2} \mathrm{H}_{2} \mathrm{O}(0.5 \mathrm{ml}$, 99.8 atom $\%$ excess) and spectra were determined with a Perkin-Elmer R32 spectrometer operated at $60 \mathrm{MHz}$.

\section{Preparation of potassium lactate-2-sulphates}

Lithium lactate $(0.1 \mathrm{~mol}$, racemic or L-isomer) was slowly added to stirred conc. $\mathrm{H}_{2} \mathrm{SO}_{4}(1 \mathrm{~mol}$, cooled in an ice/salt bath) care being taken to ensure the temperature remained below $20^{\circ} \mathrm{C}$. After addition, stirring was continued for $3 \mathrm{~h}$ at room temperature. The reaction mixture was poured into 1 litre of ice-cold water containing $100 \mathrm{~g}$ of $\mathrm{Ba}(\mathrm{OH})_{2}$, and more solid $\mathrm{Ba}(\mathrm{OH})_{2}$ was added until the $\mathrm{pH}$ was greater than 7. Precipitated $\mathrm{BaSO}_{4}$ and undissolved $\mathrm{Ba}(\mathrm{OH})_{2}$ were removed by centrifuging and excess $\mathrm{Ba}(\mathrm{OH})_{2}$ was precipitated as $\mathrm{BaCO}_{3}$ by passing $\mathrm{CO}_{2}$ through the ice-cold solution. After centrifuging, the supernatant was concentrated (in vacuo at $40-45^{\circ} \mathrm{C}$ ) to about $100 \mathrm{ml}$. The concentrate was passed through a Dowex 50 column $\left(\mathrm{H}^{+}\right.$form $\left.; 3 \mathrm{~cm} \times 18 \mathrm{~cm}\right)$ and the eluate that emerged at $\mathrm{pH} 1-2$ was collected and neutralized with $\mathrm{KOH}$. After concentrating to $50 \mathrm{ml}$ as before, the solution was applied to a Dowex 1 column $\left(\mathrm{HCO}_{3}{ }^{-}\right.$form; $\left.3 \mathrm{~cm} \times 27 \mathrm{~cm}\right)$ which was then eluted with a linear gradient of $\mathrm{NH}_{4} \mathrm{HCO}_{3}(1.0$ $1.5 \mathrm{M})$ and then continuously with $1.5 \mathrm{M}$ $\mathrm{NH}_{4} \mathrm{HCO}_{3}$. Fractions $(10 \mathrm{ml})$ were tested for the presence of the sulphate ester group (acid hydrolysis plus $\mathrm{BaCl}_{2}$ ) and the positive fractions were pooled. Sufficient Dowex $50\left(\mathrm{H}^{+}\right.$form) was added to make the solution acidic (about $\mathrm{pH} 3$ ) and the whole was then de-gassed in vacuo, neutralized with $\mathrm{KOH}$ and freeze-dried. The product was recrystallized from water/methanol $(9: 1, \mathrm{v} / \mathrm{v})$. The yield of racemic lactate-2-sulphate was $34.3 \%$ and the chemical analysis was: $\mathrm{C}, 14.17 \%$ found $(14.63 \%$ theoretical $) ; \mathrm{H}, 1.52 \%(1.63 \%) ; \mathrm{SO}_{4}$, $37.6 \%(39.0 \%) ; \mathrm{K}^{+}, 31.6 \%(31.7 \%)$. For L-lactate-2sulphate the yield was $39.1 \%$ and the chemical ana- lysis; $\mathrm{C}, 14.96 \% ; \mathrm{H}, 1.58 \% ; \mathrm{SO}_{4}, 39.4 \% ; \mathrm{K}^{+}, 32.4 \%$ (theoretical values as for racemic compound). I.r. spectroscopy revealed strong absorption bands at $1200-1260 \mathrm{~cm}^{-1}$ and $770-820 \mathrm{~cm}^{-1}$ typical of covalent sulphate esters, and at $1600 \mathrm{~cm}^{-1}$, characteristic of the carboxylate group. The n.m.r. spectrum of lactate-2-sulphate (racemic or L-isomer) contained a doublet $\left[\delta\right.$ (p.p.m.) $\left({ }^{2} \mathrm{H}_{2} \mathrm{O}\right) 1.40(3 \mathrm{H}, \mathrm{d}, J$ $\left.\left.5 \mathrm{~Hz}, \mathrm{CH}_{3} \mathrm{CH}\right)\right]$ shifted slightly downfield from the corresponding signal in the lactic acid spectrum $(\delta=1.28)$. The signal for the $\mathrm{C}-2$ proton of lactate [ $\delta$ (p.p.m.) $\left.\left({ }^{2} \mathrm{H}_{2} \mathrm{O}\right) 4.00\left(1 \mathrm{H}, \mathrm{q}, J 4 \mathrm{~Hz}, \mathrm{CH}_{3} \mathrm{CH}\right)\right]$ was also shifted downfield in the sulphate ester and was partly obscured by the ${ }^{1} \mathrm{H}^{2} \mathrm{HO}$ resonance.

D-Lactate-2-sulphate was prepared in a similar manner except that the solution emerging from the Dowex 50 column was neutralized $(\mathrm{KOH})$ and freeze-dried, and the residue was extracted with methanol. The white solid remaining was washed with diethyl ether, dried at $60^{\circ} \mathrm{C}$, and then recrystallized as before. Adoption of this procedure enabled expensive unchanged D-lactate to be recovered from the methanol extracts. The yield of Dlactate-2-sulphate was $29.8 \%$ and the results of chemical and spectroscopic analyses were virtually identical to those for the racemic compound.

\section{Preparation of alkyl sulphates}

Primary alkyl sulphates and racemic 'decan-5-yl sulphate' (containing other decyl sulphate isomers; see Matcham \& Dodgson, 1977) were prepared from the parent alcohols by the method of Dodgson et al. (1974). Potassium propan-2-yl sulphate was prepared by the method of Lloyd et al. (1961) scaled up 50-fold. Other secondary alkyl sulphates were prepared by the method of White et al. (1980). Most values for $\mathrm{C}$ and $\mathrm{H}$ contents were within $2 \%$ and $0.2 \%$ of theoretical values, respectively. Percentage contents of $\mathrm{SO}_{4}$ and $\mathrm{K}^{+}$were within $2 \%$ and $1 \%$ of expected values. I.r. spectra contained strong absorption bands at $1200-1260$ and 770 $810 \mathrm{~cm}^{-1}$ typically associated with sulphate esters (Lloyd et al., 1961). N.m.r. spectra of alkyl sulphate esters conformed to the patterns described previously (White et al., 1980).

\section{Growth of Pseudomonas syringae GG}

The bacterium (the isolation of which will be described elsewhere) was grown on a large scale ( 400 litre New Brunswick Fermentor) in 350 litres of basal salts (Fitzgerald \& Payne, 1972) supplemented with potassium propan-2-yl sulphate $(0.3 \%)$. The fermentor was aerated with $1.0 \mathrm{~m}^{3}$ of air $/ \mathrm{h}$ and was agitated at $60 \mathrm{rev} . / \mathrm{min}$. Cells were harvested after $20 \mathrm{~h}$ (stationary phase) with a Sharples centrifuge (flow rate 90 litres/h) and the wet cells (approx. $1 \mathrm{~kg}$ ) were resuspended in water, freeze-dried and stored at $-20^{\circ} \mathrm{C}$ until required. 


\section{Assay of sulphatase activity}

Enzymically liberated $\mathrm{SO}_{4}{ }^{2-}$ ions were measured by the $\mathrm{BaCl}_{2}$ /gelatin method of Dodgson (1961) as modified by Thomas \& Tudball (1967). Enzyme and substrate were routinely incubated at $25^{\circ} \mathrm{C}$ in the presence of $0.1 \mathrm{M}-\mathrm{Tris} / \mathrm{HCl}$ buffer, $\mathrm{pH} 7.5$, and appropriate control determinations were made. A unit of enzyme activity is defined as the amount of enzyme that liberates $1 \mu \mathrm{mol}$ of $\mathrm{SO}_{4}{ }^{2-} / \mathrm{min}$ at $25^{\circ} \mathrm{C}$ when $10 \mathrm{mM}$-D-lactate-2-sulphate is employed as substrate.

For assays performed during enzyme purification, incubation periods varied depending upon circumstances. For kinetic work, preliminary experiments with pure enzyme indicated that sulphate release was linear with time over a $5 \mathrm{~min}$ period provided that the extent of hydrolysis did not exceed $15 \%$ of the substrate. The activity of the pure enzyme was proportional to protein concentration up to at least $32 \mu \mathrm{g} / \mathrm{ml}$ of incubation mixture.

\section{Determination of protein and nucleic acid}

Protein contents of column fractions were estimated by measuring $A_{280}$. Protein concentrations in pooled fractions at each stage of purification were determined by the method of Lowry et al. (1951), with bovine serum albumin (fraction V) as standard. Nucleic acid was determined by the method of Layne (1957).

\section{Determination of lactate}

In order to establish the reaction stoicheiometry and the configuration of the lactic acid liberated as a result of enzyme action, $D$ - and L-lactic acids were assayed using either D- or L-lactate dehydrogenase and the method described in the Sigma Technical Bulletin no. 826-UV.

\section{Polyacrylamide-gel electrophoresis}

Conditions used for separating and locating primary and secondary alkylsulphatases on gels were as described by Payne et al. (1974). Sodium dodecyl sulphate was the substrate for the detection of the primary enzymes and 'decan-5-yl sulphate' for the secondaries. Staining of gels for lactate-2-sulphatase activity was carried out by incubating gels with a solution containing $20 \mathrm{~mm}$-potassium lactate-2-sulphate and $20 \mathrm{~mm}$-barium acetate in $0.1 \mathrm{M}$ $\mathrm{Tris} / \mathrm{HCl}, \mathrm{pH}$ 7.5. Enzyme activity revealed itself as a white band of precipitated $\mathrm{BaSO}_{4}$.

Staining of gels for ability to dechlorinate potassium DL-2-chloropropionate (the chloro-analogue of DL-lactate 2-sulphate) was achieved by using the $\mathrm{AgNO}_{3}$ precipitation method of Weightman \& Slater (1980) except that the incubation buffer was $0.1 \mathrm{M}$-Tris $/ \mathrm{H}_{2} \mathrm{SO}_{4}, \mathrm{pH} 7.5$, and the substrate con- centration was $20 \mathrm{~mm}$. This procedure reveals dehalogenase activity as a band of insoluble $\mathrm{AgCl}$.

Staining for protein was according to the directions of Diezel et al. (1972) except that Page Blue G90 was substituted for Coomassie Brilliant Blue G250.

\section{Isotope-incorporation experiments}

Incorporation of ${ }^{18} \mathrm{O}$ from water into one or other of the products of the reaction catalysed by the enzyme was examined. A reaction mixture containing $25 \mu \mathrm{mol}$ of D-lactate-2-sulphate dissolved in $250 \mu \mathrm{l}$ of $\mathrm{H}_{2}{ }^{18} \mathrm{O}$ (70 atom\% excess), pure D-lactate-

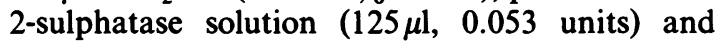
$0.4 \mathrm{M}$-Tris $/ \mathrm{HCl}, \mathrm{pH} 7.5(125 \mu \mathrm{l})$, was incubated at $25^{\circ} \mathrm{C}$ for $6 \mathrm{~h}$. Under these conditions, the extent of hydrolysis was in excess of $90 \%$. Reaction was stopped by addition of $100 \mu \mathrm{l}$ of $10 \mathrm{M}-\mathrm{HCl}$ and liberated inorganic sulphate was precipitated immediately by adding $200 \mu \mathrm{l}$ of a hot saturated solution of $\mathrm{BaCl}_{2}$. The precipitate was separated by centrifuging and set aside. The supernatant was extracted with diethyl ether $(10 \times 1 \mathrm{ml})$ and the pooled extracts containing enzymically liberated lactic acid were evaporated to dryness in a stream of $\mathrm{N}_{2}$. The residue was redissolved in methanol and analysed in a Finnegan 4500 gas chromatograph/mass spectrometer to determine the extent of ${ }^{18} \mathrm{O}$ incorporation from water that had occurred during hydrolysis. The mass spectrum obtained by chemical ionization was identical with that of standard unenriched lactic acid. The main peak at $\mathrm{m} / \mathrm{z} 91$ corresponded to $(M+\mathrm{H})$, where $M$ is the molecular ion.

The precipitated $\mathrm{BaSO}_{4}$ was washed (distilled water, $3 \times 1 \mathrm{ml}$; methanol, $3 \times 1 \mathrm{ml}$; diethyl ether, $4 \times 1 \mathrm{ml})$, mixed with finely ground $\mathrm{KBr}(150 \mathrm{mg})$ and oven-dried at $90^{\circ} \mathrm{C}$. The mixture was compressed into a disc and its i.r. spectrum in the range $800-1400 \mathrm{~cm}^{-1}$ was recorded. The ${ }^{18} \mathrm{O}$ enrichment of the $\mathrm{BaSO}_{4}$ was calculated from absorptions at $970 \mathrm{~cm}^{-1}$ and $990 \mathrm{~cm}^{-1}$ according to the method of Spencer (1959).

\section{Purification of D-lactate-2-sulphatase}

Stage 1. Freeze-dried cells $(2 \mathrm{~g})$ of the bacterium were resuspended in $30 \mathrm{ml}$ of ice-cold $10 \mathrm{~mm}$ Tris/ $\mathrm{HCl}$ buffer, $\mathrm{pH} 7.5$, and stirred mechanically for $30 \mathrm{~min}$ at $2^{\circ} \mathrm{C}$. The cell suspension was then passed four times through a chilled French press at a pressure of $120 \mathrm{MPa}$. Cell debris was removed by centrifuging for $1 \mathrm{~h}$ at $4^{\circ} \mathrm{C}$ and $31000 g_{\text {av. }}$ (SS34 rotor, Sorvall RC-5B centrifuge) and the clear supernatant was dialysed against the resuspension buffer ( $3 \times 2$ litres) for a total of $18 \mathrm{~h}$.

Stage 2. The protein concentration of the dialysed extract $(31 \mathrm{ml})$ was adjusted to $10 \mathrm{mg} / \mathrm{ml}$ with buffer and sufficient streptomycin sulphate 
solution $(5 \%, w / v)$ was added to the stirred solution to bring the concentration of the streptomycin sulphate also to $10 \mathrm{mg} / \mathrm{ml}$. Stirring was continued for $30 \mathrm{~min}$, when precipitated nucleic acid was removed by centrifuging as before and the clear supernatant was dialysed against $10 \mathrm{mM}-\mathrm{Tris} / \mathrm{HCl}$ buffer $(4 \times 5$ litres $)$ for $18 \mathrm{~h}$ at $4^{\circ} \mathrm{C}$.

Stage 3. The cell extract from stage 2 (approx. $120 \mathrm{ml}$ ) was treated with a settled suspension of DEAE-cellulose (DE52, 25 ml) in $10 \mathrm{~mm}$-Tris $/ \mathrm{HCl}$ buffer, $\mathrm{pH}$ 7.5. The mixture was left for $15 \mathrm{~min}$ at $2^{\circ} \mathrm{C}$. with occasional stirring and then centrifuged for $15 \mathrm{~min}$ at $10000 \mathrm{~g}_{\text {av. }}$ and $4^{\circ} \mathrm{C}$. The supernatant was decanted and the pellet was resuspended in $10 \mathrm{~mm}$-Tris/ $\mathrm{HCl}$ buffer $(25 \mathrm{ml}, \mathrm{pH} 7.5)$ and stirred for $10 \mathrm{~min}$ : After centrifuging, the supernatant was discarded and the pellet was washed with $0.2 \mathrm{M}$ $\mathrm{NaCl}(2 \times 25 \mathrm{ml})$ and $0.5 \mathrm{M}-\mathrm{NaCl}(2 \times 25 \mathrm{ml})$ with intermediate centrifuging. The $0.5 \mathrm{M}-\mathrm{NaCl}$ eluates were pooled and dialysed against $50 \mathrm{~mm}-$ Tris $/ \mathrm{HCl}$ buffer, $\mathrm{pH} 7.5(3 \times 5$ litres $)$ for $18 \mathrm{~h}$.

Stage 4. The extract from stage 3 was applied to a DE52 column $(4.3 \mathrm{~cm} \times 45 \mathrm{~cm})$ that had been equilibrated with $50 \mathrm{~mm}$-Tris/HCl buffer, $\mathrm{pH} 7.5$. The column was washed with $100 \mathrm{ml}$ of the same buffer and then eluted with a linear gradient of $\mathrm{NaCl}(0.2-0.5 \mathrm{M})$ in the $\mathrm{Tris} / \mathrm{HCl}$ buffer (total volume, $1500 \mathrm{ml}$ ). Flow rate was adjusted to $75 \mathrm{ml} / \mathrm{h}$ and $10 \mathrm{ml}$ fractions were collected and monitored for protein and enzyme activity. Fractions with the highest specific enzyme activity were pooled (fractions 95-104, see Fig. 1a), concentrated (Millipore CX 10 immersible membrane) to $10 \mathrm{ml}$ and dialysed for $18 \mathrm{~h}$ against $0.1 \mathrm{M}$ Tris/HCl buffer, $\mathrm{pH} 7.5$ (3 $\times 5$ litres).

Stage 5. The stage 4 enzyme was applied to a Sephacryl S-300 column $(2.5 \mathrm{~cm} \times 80 \mathrm{~cm})$ that had been equilibrated with $0.1 \mathrm{M}-\mathrm{Tris} / \mathrm{HCl}, \mathrm{pH} 7.5$. The column was eluted with the same buffer at a flow rate of $5 \mathrm{ml} / \mathrm{h}$ and $6 \mathrm{ml}$ fractions were collected.

Stage 6. Stage 5 fractions containing the highest specific activity (fractions $34-38$, see Fig. $1 b$ ) were pooled and applied to a butyl-agarose column
$(1.6 \mathrm{~cm} \times 40 \mathrm{~cm})$ that had been equilibrated with $10 \mathrm{~mm}$-Tris/HCl, $\mathrm{pH} 7.5$. The column was washed with the buffer $(20 \mathrm{ml})$ followed by a linear gradient of $\mathrm{NaCl}(0-0.015 \mathrm{M})$ in $800 \mathrm{ml}$ of buffer. Fractions containing enzyme as a single protein band on gel electrophoretograms were combined (fractions 59-64, see Fig. 1c).

\section{Results}

\section{Purification of lactate-2-sulphatase}

Table 1 provides details of the activities and recoveries of the enzyme during a typical purification procedure. Problems were encountered when attempts were made to scale-up the purification procedure in that the final preparation was contaminated with a minor protein component. Multiple preparations on a $2 \mathrm{~g}$ (dried cells) scale were consistently satisfactory. Tests for primary and secondary alkylsulphatases in polyacrylamide gels of the crude cell extract and the final preparation (using sodium dodecyl sulphate and 'decan-5yl sulphate' as the respective substrates) were negative.

\section{Determination of $M_{r}$}

Sodium dodecyl sulphate/polyacrylamide-gel electrophoresis gave a single band corresponding to an $M_{\mathrm{r}}$ of 55000 . Carbonic anhydrase (bovine erythrocytes), albumin (chicken egg), albumin (bovine serum), phosphorylase $b$ (rabbit mucle), $\beta$ galactosidase (Escherichia coli) and myosin (rabbit muscle) were the standard proteins.

The $M_{\mathrm{r}}$ of the purified native enzyme was determined by the electrophoretic method of Zwann (1967) using ferritin (horse spleen), catalase (bovine liver), aldolase (rabbit muscle), albumin (chicken egg), albumin (bovine serum) and chymotrypsin (bovine pancreas) as standard proteins. The native $M_{\mathrm{r}}$ was 59800 , suggesting a monomeric structure for the enzyme. Gel filtration on Sephacryl S-300 with the same set of standards gave an $M_{\mathrm{r}}$ of 89000 . The reason for this discrepancy is not

Table 1. Purification of D-lactate-2-sulphatase from Pseudomonas syringae GG

See the text for experimental details and for definition of the unit of enzyme activity.

\begin{tabular}{|c|c|c|c|c|c|c|c|}
\hline Purification stage & $\begin{array}{l}\text { Volume } \\
\text { (ml) }\end{array}$ & $\begin{array}{l}\text { Nucleic } \\
\text { acid } \\
(\%)\end{array}$ & $\begin{array}{l}\text { Protein } \\
\text { (mg) }\end{array}$ & $\begin{array}{l}\text { Enzyme } \\
\text { activity } \\
\text { (units) }\end{array}$ & $\begin{array}{c}\text { Specific } \\
\text { activity } \\
\text { (units } / \mathrm{mg} \text { ) }\end{array}$ & $\begin{array}{l}\text { Recovery } \\
(\%)\end{array}$ & $\begin{array}{l}\text { Purification } \\
\text { (fold) }\end{array}$ \\
\hline 1. Cell extracts & 31 & 17 & 1088 & 48.9 & 0.045 & 100 & 1.0 \\
\hline 2. Streptomycin sulphate & 123 & 1.75 & 745 & 80.2 & 0.106 & 164 & 2.4 \\
\hline $\begin{array}{l}\text { 3. DEAE-cellulose } \\
\text { batch treatment }\end{array}$ & 52 & & 250 & 47.4 & 0.190 & 94 & 4.3 \\
\hline $\begin{array}{l}\text { 4. DEAE-cellulose } \\
\text { column }\end{array}$ & 10 & & 9.2 & 30.3 & 3.3 & 62 & 73 \\
\hline 5. Sephacryl S-300 & 30 & & 5.3 & 24.4 & 4.6 & 50 & 101 \\
\hline 6. Butyl-agarose & 47 & & 1.03 & 11.3 & 10.9 & 23 & 243 \\
\hline
\end{tabular}



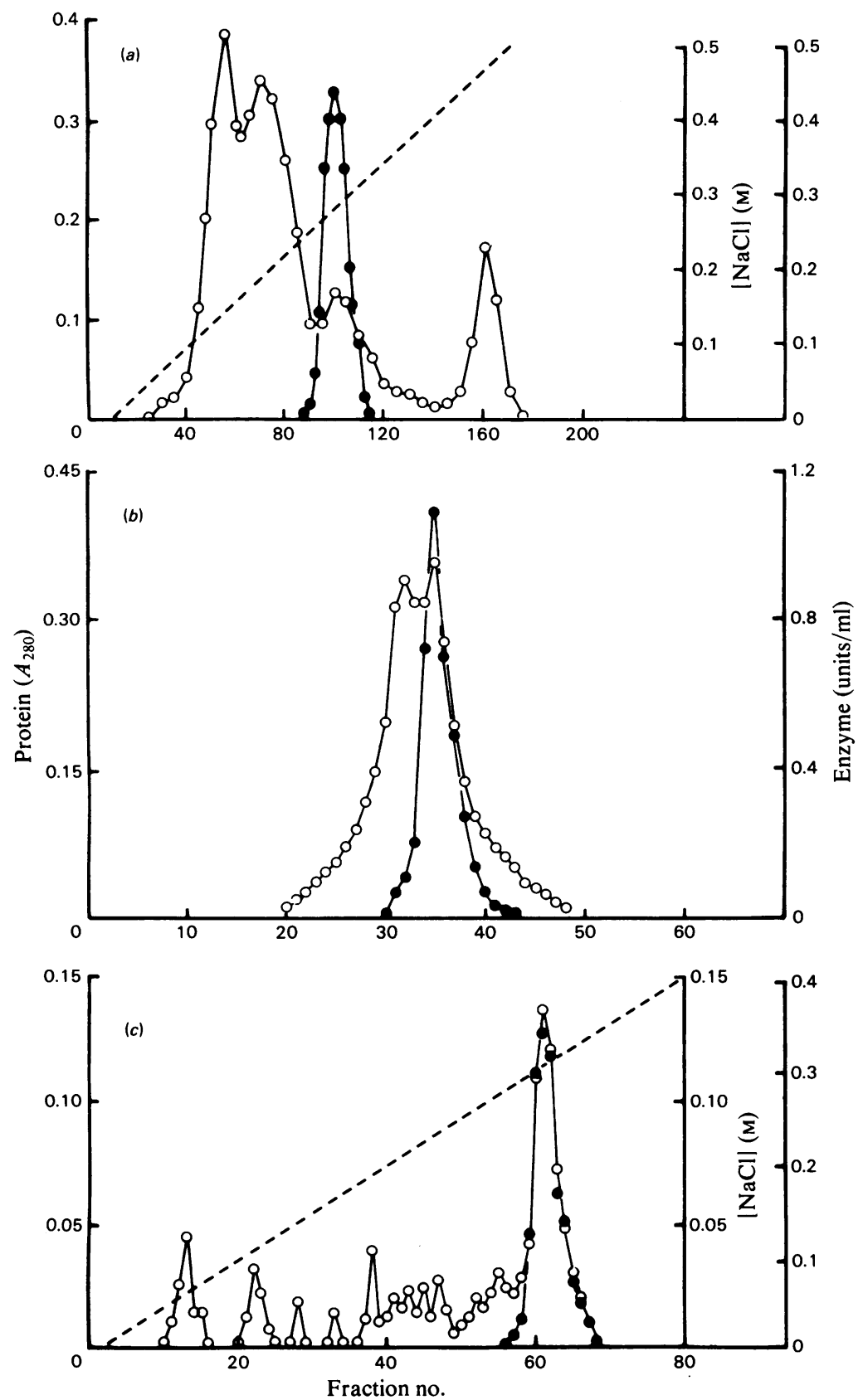

Fig. 1. Elution profiles for D-lactate-2-sulphatase from DEAE-cellulose, Sephacryl S-300 and butyl-agarose

(a) Elution from DEAE-cellulose (DE52) at stage 4 of the purification; (b) elution from Sephacryl S-300 at stage 5; (c) elution from butyl-agarose at stage 6 . See the text for details. $\bigcirc$, Protein;, , D-lactate-2-sulphatase activity;---;, $\mathrm{NaCl}$ concentration gradient.

known, but problems encountered with gel filtration columns during the purification had indicated that some sort of aggregation might be occurring.

\section{Thermal stability}

Purified enzyme, in buffer at $\mathrm{pH} 7.5$, was preincubated for $5 \mathrm{~min}$ at various temperatures from 15 to $50^{\circ} \mathrm{C}$ in the absence of substrate. Subsequently samples of the enzyme were assayed in the usual way at $25^{\circ} \mathrm{C}$. The enzyme was stable to preincubation at temperatures up to $25^{\circ} \mathrm{C}$ but at higher temperatures there was a steady decrease in activity until at $50^{\circ} \mathrm{C}$ no activity remained. When enzyme was assayed at different temperatures without pre-

Vol. 223 
incubation, there was a marked (3-fold) increase in activity from 15 to $25^{\circ} \mathrm{C}$ and a maximum at $35^{\circ} \mathrm{C}$ beyond which thermal inactivation caused a decrease in activity.

\section{Substrate specificity}

Initial experiments with dialysed crude cell extracts showed that the enzymic reaction ceased when approx. $50 \%$ of the racemic lactate-2-sulphate preparation had been hydrolysed. Addition of further cell extract (so that the enzyme concen-

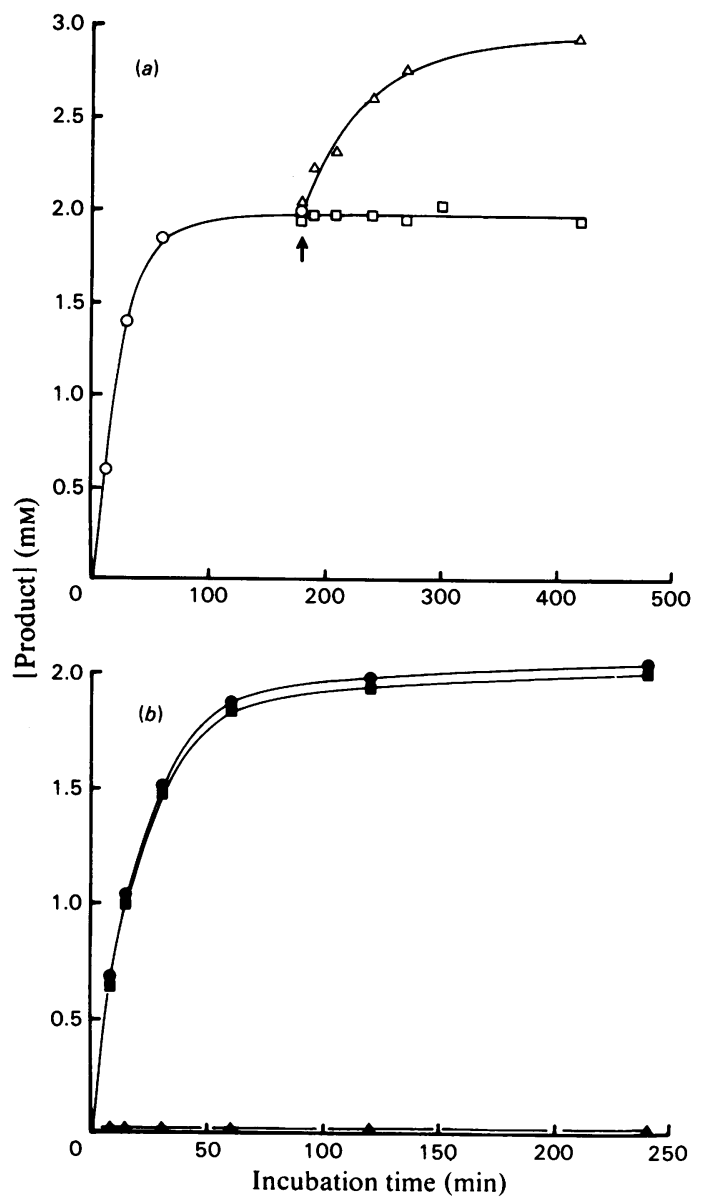

Fig. 2. Reaction progress curves for the enzymic hydrolysis of racemic and D-lactate-2-sulphate

(a) $\mathrm{O}$, Enzymic release of $\mathrm{SO}_{4}{ }^{2-}$ from a solution containing $4 \mathrm{mM}$-DL-lactate-2-sulphate and 0.12 unit of enzyme $/ \mathrm{ml}$ in $0.1 \mathrm{M}$-Tris $/ \mathrm{HCl}$, pH 7.5. At the arrow, the incubation mixture was further supplemented so that either $(\square)$ the enzyme concentration was raised to $0.18 \mathrm{unit} / \mathrm{ml}$, or $(\Delta)$ the total substrate concentration was raised to $6 \mathrm{mM}$. (b) Hydrolysis products released from $2 \mathrm{~mm}$-D-lactate-2-sulphate in a solution containing 0.12 units of enzyme/ml of $0.1 \mathrm{M}$-Tris/HCl, $\mathrm{pH}$ 7.5. O, Inorganic sulphate; $\square$, D-lactate; $\boldsymbol{\Lambda}$, L-lactate. tration was doubled) at this point did not cause any further hydrolysis of substrate. On the other hand, addition of further racemic substrate (so that the original concentration was doubled) gave a further hydrolysis equivalent to about $42 \%$ of the additional substrate. These findings were confirmed in similar experiments with pure enzyme (Fig. $2 a$ ). This suggested that the enzyme was hydrolysing only one of the optical stereoisomers present in the racemic substrate. Other experiments in which either the D- or the L-isomer was incubated with the purified enzyme showed that only the D-form could serve as a substrate. Time-course experiments in which D-lactate-2-sulphate was completely hydrolysed by the pure enzyme showed that $\mathrm{SO}_{4}{ }^{2-}$ ions and D-lactate were released at the same rate (Fig. $2 b$ ) and no L-lactate was produced.

A wide variety of other sulphate esters was tested as possible substrates for the enzyme. Potential substrates were present at a final concentration of $20 \mathrm{~mm}$ and the $\mathrm{pH}(7.5)$ was optimal for the normal substrate. Of the 29 compounds tested, only two served as substrates (albeit very poor ones) for the enzyme. D-Serine- $O$-sulphate was hydrolysed at a rate equivalent to $9 \%$ of that of D-lactate-2-sulphate, whereas $p$-nitrophenyl sulphate was hydrolysed at a rate equivalent to $6 \%$. The sulphate esters of L-lactate, methanol, ethanol, propanol, propan2-ol, butanol, butan-2-ol, pentanol, pentan-2-ol, pentan-3-ol, hexanol, hexan-2-ol, heptanol, heptan-2-ol, heptan-4-ol, octanol, octan-2-ol, decanol, decan-5-ol, 2-hydroxybutyrate, 2-hydroxyisobutyrate, butoxyethanol and phenoxyethanol, the 6-sulphate esters of glucosamine and $\mathrm{N}$-acetylglucosamine, and the 3-sulphate esters of glucosamine and $N$-acetylgalactosamine were not substrates for lactate-2-sulphatase. When gels containing pure D-lactate-2-sulphatase were incubated with potassium DL-2-chloropropionate (the chloroanalogue of DL-lactate-2-sulphate) no white bands were observed, indicating the absence of dehalogenase activity.

In the light of these findings, it is proposed that the enzyme be referred to as D-lactate-2-sulphatase.

\section{Position of bond cleavage}

Retention of configuration at C-2 during enzymic hydrolysis of D-lactate-2-sulphate strongly implicated the $\mathrm{O}-\mathrm{S}$ bond as the cleavage site in the $\mathrm{C}-\mathrm{O}-\mathrm{S}$ linkage. When enzymic hydrolysis of $\mathrm{D}$ lactate-2-sulphate was performed in the presence of $\mathrm{H}_{2}{ }^{18} \mathrm{O}$ ( 35 atom\% excess), there was no significant incorporation of ${ }^{18} \mathrm{O}$ above natural abundance into $\mathrm{D}$-lactate. In contrast, the ${ }^{18} \mathrm{O}$-enrichment of the $\mathrm{SO}_{4}{ }^{2-}$ ions was 8.92 atom $\%$ excess, in close agreement with the theoretical value of $8.75 \%$ for O-S cleavage. This, and the failure to find any 


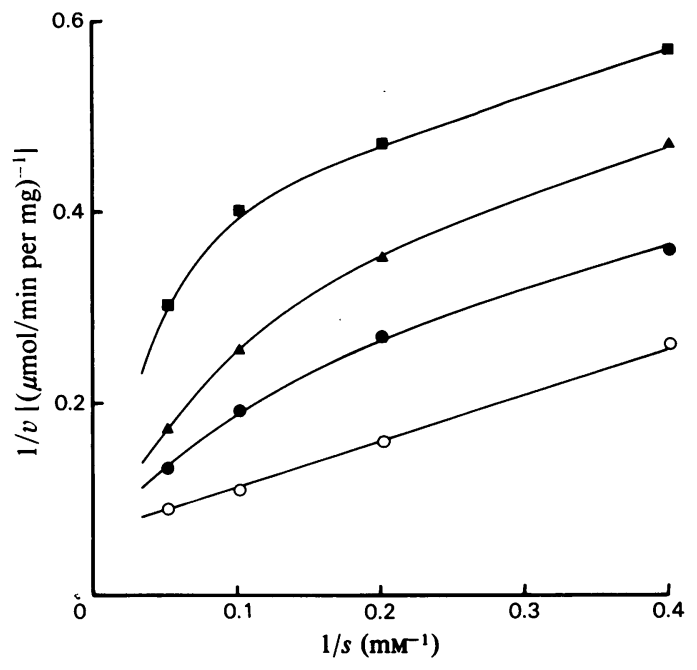

Fig. 3. Product inhibition of D-lactate-2-sulphatase by Dlactate

D-Lactate-2-sulphatase was assayed in the presence of $0(O), 6.25 \mathrm{~mm}(O), 12.5 \mathrm{~mm}(\Delta)$ and $25.0 \mathrm{~mm}(\square)$ concentrations of D-lactate under the usual assay conditions. Liberated sulphate was assayed at $1 \mathrm{~min}$ intervals up to $10 \mathrm{~min}$ to provide accurate initial velocity measurements.

enrichment in the D-lactate co-product, proved conclusively that D-lactate-2-sulphatase acts upon the $\mathrm{O}-\mathrm{S}$ bond of the $\mathrm{C}-\mathrm{O}-\mathrm{S}$ ester linkage.

\section{Effect of $\mathrm{pH}$ and substrate concentration}

Maximum enzyme activity towards $15 \mathrm{~mm}$-Dlactate-2-sulphate was obtained at pH7.5. Tris/ $\mathrm{HCl}$ buffer $(0.2 \mathrm{M})$ was used to cover the $\mathrm{pH}$ range 7.0-9.0 and acetic acid/ $\mathrm{NaOH}$ buffer $(0.2 \mathrm{~mm})$ to cover the range $\mathrm{pH6}$ 6-7.5. The $K_{\mathrm{m}}$ value at $\mathrm{pH} 7.5$ as determined by a double-reciprocal plot was $6.7 \mathrm{~mm}$ (maximal specific activity $14.3 \mu \mathrm{mol} / \mathrm{min}$ per $\mathrm{mg}$ of protein) and by the direct linear plot (Eisenthal \& Cornish-Bowden, 1974) was $6.6 \mathrm{~mm}$ (maximal specific activity $14.8 \mu \mathrm{mol} /$ min per $\mathrm{mg}$ of protein).

\section{Effects of inhibitors}

Potassium L-lactate-2-sulphate inhibited the enzyme in a non-competitive manner with $K_{\mathrm{i}}=16.3 \mathrm{mM} \quad$ (Lineweaver-Burk plot). D-Lactic acid, a product of the enzyme's action on D-lactate2-sulphate, also inhibited the enzyme but the double reciprocal plots were non-linear (Fig. 3). At low substrate concentrations, the curves were parallel and the inhibition resembled the uncompetitive type. At high substrate concentrations the curves converged. L-Lactic acid was not an inhibitor. Several other compounds, mainly sulphate
Table 2. Some inhibitors of D-lactate-2-sulphatase

Pure enzyme was incubated with D-lactate-2-sulphate $(20 \mathrm{mM})$ and each potential inhibitor $(20 \mathrm{mM}$ unless stated otherwise) in the normal assay buffer for $4 \mathrm{~min}$. Liberated $\mathrm{SO}_{4}{ }^{2-}$ was determined as described in the text and activities are expressed as percentages of that observed in the absence of inhibitor.

Inhibitor $\quad$ Residual activity $(\%$

D-Lactic acid 53

L-Lactate-2-sulphate (12 mM) $\quad 57$

Glycollate-2-sulphate $\quad 58$

Butyrate-2-sulphate $\quad 58$

Propan-1-yl sulphate $\quad 78$

Propan-2-yl sulphate $\quad 82$

Butan-2-yl sulphate $\quad 75$

Pentan-3-yl sulphate $\quad 90$

Hexan-2-yl sulphate $\quad 87$

D-Serine- $O$-sulphate $\quad 89$

2-Chloropropionate $\quad 92$

esters, were also tested as potential inhibitors of the enzyme (Table 2). Not surprisingly, D-lactic acid and L-lactate-2-sulphate were the best inhibitors. Glycollate-2-sulphate and butyrate-2-sulphate, which are carbon chain-length homologues of lactate-2-sulphate, were also inhibitory, but chloropropionate and other sulphate esters tested were weak inhibitors.

\section{Discussion}

The purification factor of 243-fold achieved for D-lactate-2-sulphatase is typical of other inducible bacterial alkylsulphatases that have been purified hitherto (Cloves et al., 1980; Shaw et al., 1980; Lillis et al., 1983). Other similarities exist; for example, the enzyme is stereospecific, it exhibits an alkaline $\mathrm{pH}$ optimum, and it acts as a simple sulphatase releasing sulphate and D-lactate in stoicheiometric amounts. However, there are also some significant differences. First, D-lactate-2sulphatase catalyses fission of the $\mathrm{O}-\mathrm{S}$ bond of the $\mathrm{C}-\mathrm{O}-\mathrm{S}$ ester linkage, whereas the simple alkylsulphatases of Pseudomonas C12B and Comamonas terrigena cleave at the $\mathrm{C}-\mathrm{O}$ bond. In this respect the D-lactate-2-sulphatase is like the 2,4-dichlorophenoxyethyl sulphatase (Crag herbicide sulphatase) of P. putida (Lillis et al., 1983), which is the only other alkylsulphatase known to act at the O-S bond. Secondly, D-lactate-2-sulphatase has a very narrow substrate specificity, failing to hydrolyse even glycollate-2-sulphate or butyrate-2-sulphate (the immediate homologues of D-lactate-2-sulphate), or any of a number of other simple primary or secondary alkyl sulphates. In contrast, the alkyl sulphatases of Pseudomonas C12B and C. 
terrigena are characterized by their ability to accept a wide range of chain lengths above a minimum around $\mathrm{C}_{5}-\mathrm{C}_{6}$. Even the $\mathrm{Crag}$ herbicide sulphatase shows activity towards long chain alkyl sulphates, including octyl and dodecyl sulphates. The narrow specificity of D-lactate-2-sulphatase is thus unusual for this type of enzyme. The ability of serine- $O$-sulphate and $p$-nitrophenyl sulphate to serve as substrates was, at first, surprising. However, construction of space-filling models showed a close similarity in size and overall structure with Dlactate-2-sulphate. Moreover the propensity of aryl sulphates for the $\mathrm{S}-\mathrm{O}$ mode of hydrolysis that this enzyme catalyses is well-established (Dodgson et al., 1982). Absence of any dehalogenase activity associated with D-lactate-2-sulphatase is perhaps to be expected in view of the $\mathrm{O}-\mathrm{S}$ bond-splitting action of the enzyme; only a $\mathrm{C}-\mathrm{OSO}_{3}$ splitting enzyme expelling the intact $\mathrm{OSO}_{3}$ moiety of a sulphate ester might be expected to break a $\mathrm{C}-\mathrm{Cl}$ bond.

Further light was thrown on the catalytic mechanism by the inhibition patterns produced by Dlactate, one of the products of enzymic hydrolysis. The uncompetitive type of inhibition observed at low substrate concentrations could arise from a mechanism involving formation of a sulphated-enzyme $\left(\mathrm{E}-\mathrm{SO}_{3}\right)$ intermediate, and reversible departure of D-lactate prior to rate-determining hydrolysis of inorganic sulphate. High concentrations of free D-lactate would hinder further dissociation of D-lactate from the $\mathrm{E}-\mathrm{SO}_{3} \cdots \mathrm{D}$-lactate complex, thereby inhibiting (uncompetitively) subsequent release of sulphate. Such a mechanism would be compatible with $\mathrm{O}-\mathrm{S}$ cleavage, and with the absence of inhibition by L-lactate which would have the wrong stereochemistry. The picture becomes further complicated at high concentrations of substrate, which alleviate the inhibitory effects of Dlactate (Fig. 3). A possible explanation of this observation may be that excess substrate and Dlactate now compete for binding to $\mathrm{E}-\mathrm{SO}_{3}$, but the $\mathrm{E}-\mathrm{SO}_{3} \cdots \mathrm{D}$-lactate-2-sulphate complex is still able to release sulphate. A more detailed analysis of the mechanism, to accommodate both this protective effect of excess substrate and the non-competitive inhibition by L-lactate-2-sulphate, must now await further experimentation.

$P$. syringae GG grows well on propan-2-yl sulphate, but its failure to produce a corresponding sulphatase eliminates the usual pathway for alkyl sulphate degradation in micro-organisms, namely initial desulphation followed by oxidation. However, the discovery of D-lactate-2-sulphatase in extracts of cells grown on propan-2-yl sulphate strongly suggests an alternative route requiring initial oxidation of propan-2-yl sulphate to lactate2 -sulphate before desulphation to lactate. Work is currently in progress to establish the existence of this pathway, and it will be interesting to see how the stereochemistry of any oxidation steps compare with the stereospecificity of the D-lactate-2sulphatase enzyme.

We thank Professor W. J. Payne of the University of Georgia, U.S.A., for use of large-scale culture facilities, and the Department of Chemistry, University College Cardiff, for n.m.r., mass spectrometry and elemental analyses.

\section{References}

Cloves, J. M., Dodgson, K. S., White, G. F. \& Fitzgerald, J. W. (1980) Biochem. J. 185, 23-31

Denner, W. H. B., Olavesen, A. H., Powell, G. M. \& Dodgson, K. S. (1969) Biochem. J. 111, 45-51

Diezel, W., Kopperschlagger, G. \& Hofmann, E. (1972) Anal. Biochem. 48, 617-620

Dodgson, K. S. (1961) Biochem. J. 78, 312-319

Dodgson, K. S. \& White, G. F. (1983) Top. Enzyme Ferment. Biotechnol. 7, 90-155

Dodgson, K. S., Fitzgerald, J. W. \& Payne, W. J. (1974) Biochem. J. 138, 53-62

Dodgson, K. S., White, G. F. \& Fitzgerald, J. W. (1982) Sulfatases of Microbial Origin, vols. 1 and 2, CRC Press, Boca Raton, FL

Eisenthal, R. S. \& Cornish-Bowden, A. (1974) Biochem. J. 139, 715-720

Fitzgerald, J. W. \& Payne, W. J. (1972) Microbios 5, 87100

Layne, E. (1957) Methods Enzymol. 3, 447-454

Lee, M. L., Later, D. W., Rollins, D. K., Eatough, D. J. \& Hansen, L. D. (1980) Science 207, 186-188

Lillis, V., Dodgson, K. S., White, G. F. \& Payne, W. J. (1983) Appl. Environ. Microbiol. 46, 988-994

Lloyd, A. G., Tudball, N. \& Dodgson, K. S. (1961) Biochim. Biophys. Acta 52, 413-419

Lowry, O. H., Rosebrough, N. J., Farr, A. L. \& Randall, R. J. (1951) J. Biol. Chem. 193, 265-275

Matcham, G. W. J. \& Dodgson, K. S. (1977) Biochem. J. 167, 717-722

Payne, W. J., Fitzgerald, J. W. \& Dodgson, K. S. (1974) Appl. Microbiol. 27, 154-158

Shaw, D. J., Dodgson, K. S. \& White, G. F. (1980) Biochem. J. 187, 181-190

Spencer, B. (1959) Biochem. J. 73, 442-447

Thomas, J. H. \& Tudball, N. (1967) Biochem. J. 105, 467472

Weightman, A. J. \& Slater, J. H. (1980) J. Gen. Microbiol. 121, 187-193

White, G. F., Lillis, V. \& Shaw, D. J. (1980) Biochem. J. 187, 191-196

Yagi, T. (1964) Biochim. Biophys. Acta 82, 170-172

Yagi, T. (1966) J. Biochem. (Tokyo) 59, 495-500

Zwann, J. (1967) Anal. Biochem. 21, 155-168 